\title{
Karakteristik Pertumbuhan Akar dan Tajuk dua Varietas Lada Perdu (Piper nigrum L.) dengan Perlakuan Cekaman Naungan
}

\section{Characteristics of Root Growth and Heading two Varieties of Pepper (Piper nigrum L.) with Shading Stress Treatment}

\section{Siti Aminah Nasution, Chairani Hanum*, Jonatan Ginting}

Program Studi Agroekoteknologi, Fakultas Pertanian, USU, Medan 20155

*Corresponding author: hanum_chairani@yahoo.com

\begin{abstract}
Morphologi observations were a preliminary identification for plant adaptation to shading stress. This research was conducted at Cengkeh Turi, North Binjai Subdistrict (32 meters above sea) from April to June 2017, used Split Plot Design. The main plot was shade (0, 25, 50 and 75\%) and sub plot was pepper varieties (Bengkayang and Lokal Binjai). The results showed that two varieties of pepper used have same responses on the shoot dry weight, root dry weight, number of leaf area. Shading stress treatment had significant effect on shoot dry weight and number of leaf area. Lokal Binjai more adaptive to shading stress compared to Bengkayang. Light intensity $25 \%$ it is a good condition for two varieties of pepper
\end{abstract}

Keywords:, growth, shading stress, pepper.

\begin{abstract}
ABSTRAK
Pengamatan morfologi merupakan awal identifikasi untuk melihat karakteristik pertumbuhan lada pada cekaman naungan. Penelitian ini dilaksanakan di Cengkeh Turi, Kecamatan Binjai Utara (32 m dpl) pada bulan April sampai dengan Juni 2017. Penelitian menggunakan Rancangan Petak Terpisah dengan petak utama adalah cekaman naungan $(0,25,50$ dan $75 \%)$ dan anak petak adalah lada perdu (Bengkayang dan Binjai). Hasil penelitian menunjukan bahwa dua varietas lada perdu yang di gunakan memiliki respon yang sama pada bobot kering tajuk, bobot kering akar, total luas daun. Perlakuan cekaman naungan berpengaruh nyata terhadap bobot kering tajuk dan total luas daun. Lokal Binjai lebih dapat beradaptasi terhadap cekaman naungan di bandingkan dengan Bengkayang. Intensitas naungan 25\% merupakan kondisi yang baik bagi kedua varietas lada perdu.
\end{abstract}

Kata kunci : pertumbuhan, cekaman naungan, lada perdu.

\section{PENDAHULUAN}

Lada (Piper nigrum L.) merupakan salah satu tanaman rempah dimana Negara produsen terbesar di dunia adalah Indonesia, India, Malaysia dan Brasil. Secara tradisional tanaman lada diperbanyak dari sulur panjat, sehingga dalam budidaya memerlukan tiang panjat yang dapat berupa tegakan mati atau tegakan hidup (Syakir, M. 2008).

Prospek agribisnis lada di Indonesia sangat bagus yang mana hingga saat ini status usahanya $100 \%$ merupakan perkebunan rakyat. Luas pertanaman lada di Indonesia sendiri pada 3 tahun terakhir mengalami peningkatan yaitu tahun 2014 (162.747 ha), tahun 2015 (163.312 ha) dan tahun 2016 (163.986 ha). Meningkatnya luas areal pertanaman lada diiringi dengan meningkatnya hasil produksi lada selama 3 tahun terakhir yaitu pada tahun 2013 (87.445 ton/ha), tahun 2014 (88.294 ton/ha) 
dan tahun $2015 \quad(89.302$ ton/ha $)$ (Direktorat Jenderal Perkebunan, 2016).

Di Indonesia daerah sentra produksi tanaman lada terdapat di Sumatera Selatan, Bangka Belitung, Lampung, Kalimantan Timur, Kalimantan Barat, Kalimantan Tengah dan Sulawesi (Direktorat Jenderal Perkebunan, 2010). Luas areal tanam dan luas panen lada di sentrum produksi terbesar saat ini terdapat di Lampung yaitu 48.223 ha dengan produksi sebesar 15.642 ton (Direktorat Jenderal Perkebunan, 2015).

Lada perdu memerlukan naungan optimalnya $25-50 \%$, sehingga cocok dibudidayakan sebagai tanaman sela di bawah tegakan tanaman perkebunan/kehutanan seperti sengon (Albazia falcataria) dan kelapa, atau di tumpangsarikan dengan tanaman semusim seperti jagung dan kacang tanah. Beberapa keuntungan penanaman lada perdu polikultur diantaranya adalah secara konservasi dapat meningkatkan efisiensi penggunaan lahan, secara ekonomi memberikan nilai tambah terhadap pendapatan petani, dan dari segi budidaya mengurangi resiko kematian tanaman akibat cekaman lingkungan (Wahid, 1984).

Sumatera utara memiliki luasan areal di bawah tegakan yang dapat di manfaatkan untuk budidaya lada perdu. Menurut BPS luasan tersebut mencapai1.399,67 Ha.

Toleransi tanaman terhadap naungan ditentukan oleh kemampuannya melaksanakan proses fotosintesis pada naungan secara normal. Hasil di atas sejalan dengan hasil penelitian Sahardi et al. (1999) bahwa genotype toleran naungan memliki kandungan klorofil yang lebih tinggi dan sel sel mesofil yang lebih tipis. Ketebalan lapisan palisade dan mesofil dapat berubah sesuai dengan kondisi cahaya yang menyebabkan tanaman menjadi efisien dalam menyimpan energy radiasi untuk perkembangannya. Daun yang lebih luas dan lebih tipis pada keadaan ternaung di sebabkan penipisan lapisan palisade dan sel-sel mesofil yang menyebabkan tanaman menjadi lebih efisien menyimpan energy. (Mohr dan Schoopfer, 1995).
Perbedaan

tingkat naungan mempengaruhi intensitas cahaya, suhu udara, kelembaban udara, dan suhu tanah lingkungan tanaman, sehingga intensitas cahaya yang diterima oleh tanaman berbeda dan mempengaruhi ketersediaan energi cahaya yang akan diubah menjadi energi panas dan energi kimia. Semakin besar tingkat naungan (semakin kecil intensitas cahaya yang diterima oleh tanaman) maka suhu udara menjadi rendah dan kelembaban udara menjadi tinggi. Suhu yang menurunakan menyebabkan respirasi juga menurun, sedangkan kelembaban yang meningkat akan meningkatkan laju fotosintesis (Widiastuti et al., 2004).

Penelitian mengenai pengaruh naungan terhadap pertumbuhan berbagai tanaman telah banyak dilakukan. Meskipun demikian, hasil penelitian tersebut tidak dapat digeneralisir untuk semua daerah karena setiap lokasi penelitian memiliki karakter lingkungan yang berbeda (Sudarsono, 2004).

Pengamatan morfologi merupakan awal identifikasi untuk menapis tanaman yang toleran naungan. Kemampuan membentuk klorofil dan langkah awal tanaman untuk mampu menghindardaricekaman naungan.

Berdasarkan uraian di atas penulis tertarik untuk melakukan penelitian guna mempelajari karakteristik morfologi lada perdu (Piper Nigrum L.) varietas Bengkayang dan Lokal Binjai pada beberapa tingkat intensitas cahaya.

\section{BAHAN DAN METODE}

Penelitian dilaksanakan di Cengkeh turi, Binjai dengan ketinggian tempat \pm 32 meter di atas permukaan laut, mulai bulan April sampai Juli 2017.

Bahan yang digunakan adalah Bibit lada varietas Bengkayang yang berasal dari Purwekerto dan varietas Lokal Binjai yang berasal dari Binjai, top soil, pupuk kandang, pupuk NPKMg dan air, alat yang digunakan adalah paranet dengan beberapa taraf yaitu $25 \%, 50 \%, 75 \%$. 
Penelitian menggunakan rancangan petak terpisah (RPT) dengan dua faktor :

Faktor I (Petak Utama) : Tingkat naungan (N) dengan 4 taraf,yaitu: $\mathrm{N}_{0}$ : naungan $0 \%$ (kontrol), $\mathrm{N}_{1}$ : naungan $25 \%$ (intensitas cahaya $75 \%$ ), $\mathrm{N}_{2}$ : naungan $50 \%$ (intensitas cahaya 50\%), $\mathrm{N}_{3}$ : naungan $75 \%$ (intensitas cahaya 25\%), Faktor II (AnakPetak): Varietas ladaperdu, $\mathrm{V}_{1}$ : Bengkayang, $\mathrm{V}_{2}$ : Binjai.

Pelaksanaan penelitian meliputi : Pembuatan naungan dengan beberapa taraf, pengisian polybag, pemindahan tanaman, pengamatan tanaman, dan pemeliharaan tanaman meliputi penyiraman setiap pagi dan sore hari tergantung pada kondisi cuaca, penyiangan gulma dilakukan secara manual dengan mencabut gulma yang ada dalam polibag tanaman, serta pengendalian hama penyakit.Parameter yang diamati luas daun, bobot kering tajuk, bobot kering akar.

\section{HASIL PENELITIAN}

\section{Bobot Kering Tajuk}

Hasil analisis statistik diperoleh bahwa dua varietas yang digunakan tidak berbeda nyata, sedangkan cekaman naungan berpengaruh nyata terhadap bobot kering tajuk (Tabel 1).

Rataan tertinggi dari bobot kering tajuk di peroleh pada varietas Binjai, dan terendah pada Bengkayang, cekaman naungan $25 \%$ menghasilkan rataan tertinggi dan terendah pada $75 \%$. Hal ini di duga karena naungan $25 \%$ sangat optimal bagi pertumbuhan lada perdu karena dengan intensitas cahaya $75 \%$ lada dapat melakukan fotosintesis dengan baik dibandingkan dengan naungan $50 \%$ dan $75 \%$. Hal ini sesuai dengan literatur Wahid (1984) yang menyatakan bahwa Lada perdu memerlukan naungan optimalnya $25-50 \%$, sehingga cocok dibudidayakan sebagai tanaman sela di bawah tegakan tanaman perkebunan /kehutanan seperti sengon (Albazia falcataria) dan kelapa, atau di tumpangsarikan dengan tanaman semusim seperti jagung dan kacang tanah. Beberapa keuntungan penanaman lada perdu polikultur diantaranya adalah secara konservasi dapat meningkatkan efisiensi penggunaan lahan, secara ekonomi memberikan nilai tambah terhadap pendapatan petani, dan dari segi budiday amengurangi resiko kematian tanaman akibat cekaman lingkungan.

Tabel 1.Bobot kering tajuk dua varietas lada dengan cekaman naungan

\begin{tabular}{lccc}
\hline \multirow{2}{*}{ PersentaseNaungan } & \multicolumn{2}{c}{ BobotKeringTajuk } & \multirow{2}{*}{ Rataan } \\
\cline { 2 - 3 } & $\mathrm{V}_{1}$ (Bengkayang) & $\mathrm{V}_{2}($ Binjai) & \\
\hline $\mathrm{N}_{0}(0 \%)$ & 2,87 & 3,53 & $3,20 \mathrm{~b}$ \\
$\mathrm{~N}_{1}(25 \%)$ & 3,40 & 5,00 & $4,20 \mathrm{a}$ \\
$\mathrm{N}_{2}(50 \%)$ & 2,00 & 1,40 & $1,70 \mathrm{c}$ \\
$\mathrm{N}_{3}(75 \%)$ & 1,77 & 1,47 & $1,62 \mathrm{c}$ \\
\hline Rataan & 2,51 & 2,85 & \\
\hline
\end{tabular}

Keterangan :Angka-angka yang diikuti notasi yang berbeda pada baris yang sama menunjukan perbedaan yang nyata pada Uji Duncan taraf 5\%

\section{Bobot Kering Akar}

Hasil analisis menunjukkan dua varietas lada perdu tidak berbeda nyata begitu juga dengan cekaman naungan serta interaksi keduanya (Tabel 2).

Bobot kering akar lada perdu tertinggi diperoleh pada varietas Binjai dan terendah pada Bengkayang, cekaman naungan 25\% menghasilkan rataan tertingi dan terendah pada naungan $75 \%$ walaupun secara statistik tidak berpengaruh nyata. Bobot kering yang tinggi pada cekaman naungan $25 \%$ diduga disebabkan tanaman mendapatkan intensitas cahaya yang cukup. Hal ini diduga karena tanaman yang intensitas cahaya tinggi 
mendapatkan cahaya yang cukup untuk melakukan fotosintesis sehingga akan menghasilkan fotosintat yang lebih banyak dari pada tanaman yang ternaungi. Sitompul dan Guritno (1995) menjelaskan bahwa fotosintat yang lebih besar akan memungkinkan membentuk organ tanaman yang lebih besar kemudian menghasilkan produksi bahan kering yang semakin besar.

Tabel 2. Bobot kering akar dua varietas lada dengan cekaman naungan

\begin{tabular}{lccc}
\hline \multirow{2}{*}{ Persentase Naungan } & \multicolumn{2}{c}{ Bobot Kering Akar } & \multirow{2}{*}{ Rataan } \\
\cline { 2 - 3 } & $\mathrm{V}_{1}$ (Bengkayang) & $\mathrm{V}_{2}$ (Lokal Binjai) & \\
\hline $\mathrm{N}_{0}(0 \%)$ & ------------- \\
$\mathrm{N}_{1}(25 \%)$ & 0,57 & 0,83 & 0,70 \\
$\mathrm{~N}_{2}(50 \%)$ & 0,70 & 0,90 & 0,80 \\
$\mathrm{~N}_{3}(75 \%)$ & 0,13 & 0,23 & 0,18 \\
\hline Rataan & 0,17 & 0,17 & 0,17 \\
\hline
\end{tabular}

\section{Total Luas Daun}

Hasil analisis statistik menunjukkan bahwa varietas lada perdu berbeda tidak nyata sedangkan cekaman naungan berpengaruh nyata (Tabel 3).

Pengamatan rataan total luas daun varietas lada perdu tertinggi yaitu Binjai, sedangkan terendah pada Bengkayang walaupun secara statistik tidak berbeda nyata. Cekaman naungan $25 \%$ menghasilkan rataan tertinggi dan terendah pada $75 \%$. Intensitas cahaya yang semakin rendah membuat total luas daun yang rendah hal ini disebabkan untuk pembentukan luas daun dibutuhkan energi (ATP) yang bersumber dari proses Tabel 3. Total luas daun dua varietas lada dengan cekaman naungan

\begin{tabular}{lccc}
\hline \multirow{2}{*}{ Persentase Naungan } & \multicolumn{2}{c}{ Total Luas Daun } & \multirow{2}{*}{ Rataan } \\
\cline { 2 - 3 } & $\mathrm{V}_{1}$ (Bengkayang) & $\mathrm{V}_{2}$ (Lokal Binjai) & \\
\hline $\mathrm{N}_{0}(0 \%)$ & 231,28 & 317,44 & $274,36 \mathrm{ab}$ \\
$\mathrm{N}_{1}(25 \%)$ & 321,98 & 439,89 & $380,93 \mathrm{a}$ \\
$\mathrm{N}_{2}(50 \%)$ & 163,26 & 113,37 & $138,31 \mathrm{~b}$ \\
$\mathrm{~N}_{3}(75 \%)$ & 154,19 & 68,02 & $111,11 \mathrm{~b}$ \\
\hline Rataan & 217,68 & 234,68 & \\
\hline
\end{tabular}

Keterangan : Angka - angka yang diikuti oleh huruf yang sama pada baris yang sama dan pada minggu amatan yang sama menunjukkan berbeda nyata pada Uji Duncan taraf $5 \%$.

\section{SIMPULAN}

Perlakuan cekaman naungan berpengaruh nyata terhadap bobot kering fotosintat, pada cekaman naungan $75 \%$ fotosintat yang dihasilkan rendah sehingga energi tidak cukup. Hal ini sesuia dengan literatur Buntoro et al (2014) yang menyatakan bahwa daun merupakan organ utama untuk menyerap cahaya matahari. Pada daun yang lebar maka tanaman akan mampu menyerap cahaya matahari yang lebih banyak. Nilai nisbah luas daun berhubungan dengan luas daun. Bila nilai luas daun naik maka akan menyebabkan laju asimilasinya naik dan menghasilkan berat kering yang tinggi. Pada awal pertumbuhan tanaman sebagian besar difokuskan untuk pertumbuhan luas daun. Dengan meningkatnya luas daun maka akan meningkatkan pula penyerapan cahaya oleh daun. 
naungan $25 \%$ merupakan kondisi yang baik bagi kedua varietas lada perdu.

\section{DAFTAR PUSTAKA}

Buntoro, Rogomulyo dan trinowati. 2014. Pengaruh Takaran Pupuk Kandang dan Intensitas Cahaya Terhadap Pertumbuhan dan Hasil Temu Putih (Curcuma zedoaria L.), Universitas Gadjah Mada, Yogyakarta.

Direktorat Jenderal Perkebunan, 2010. Statistik Perkebunan Indonesia.

Direktorat Jenderal Perkebunan. 2015. Statistik Perkebunan Indonesia "Lada". Kementerian Pertanian, Jakarta.

Kramer, R. J. And T. T Kozlowski. 1960. Physiologi of Trees. Mc Graw Hill Book Company, New York.

Mohr H, Schopfer P. 1995. Plant Physiology. Translated by Gudrun and D.W. Lawlor.Springer.

Sudarsono Arifdan La Ode. 2014. Pengaruh Naungan Terhadap Pertumbuhan Dan Hasil Tanaman Kolesom. AGRIPLUS (24).

Suhardi, 1999. Pengaruh Persentase Naungan Terhadap Beberapa Jenis Tanaman. Bioteknologi Universitas Gajah Mada.

Sutedjo, M. M. 2002. Pupukdan Cara Pemupukan.Rineka Cipta. Jakarta.

Syakir, M. 2008. Ragam Teknologi Budidaya Lada. Perkembangan Teknologi Tanaman Rempah dan Obat, 1324.M. Syakir, 2002. Budidaya tanaman lada (Piper nigrum L.). Circuler No. 4. Balittro, $29 \mathrm{hlm}$.

Wahid, Pasril. 1994 .Pengaruh Naungan dan Pemupukan Terhadap Pertumbuhan dan Produksi Tanaman Lada. Bogor : FPS IPB.

Widiastuti, L., Tohari, E, dan Sulistyaningsih, 2004, 'Pengaruh Intensitas Cahaya dan Kadar Daminosida Terhadap Iklim Mikro dan Pertumbuhan Tanaman Krisan dalam Pot', Ilmu Pertanian, vol. 11, no. 2, hal.35-42. 